\title{
ダイヤモンド表面からの電子放出 ーディスプレイへの応用を目指して一
}

伊藤 利道*, 八田 章光**, 平木 昭夫**

\author{
Electron Emission from Diamond Surfaces
}

Toshimichi ITO*, Akimitsu HATTA** and Akio HIRAKI**

Key Words Diamond, Electron Emission, Field Emissıon, Thin Films

高輝度ディスプレイに応用可能な電子源として開発が期待されているダイヤモンドを中心とした電 子放出材料の電界放射型電子放出特性に関する研究の現状を述べ，低マク口電界で駆動できる電子放 出機構について議論するとともに, 真空に強電界を必要としない内部励起型電子放出ダイオードにつ いても言及する。

\section{1.はじめに}

フィールドエミッションディスプレイ(Field Emission Display, FED)は，現在用いられている液晶平面表 示素子が有する, 輝度, 視野角, 色彩, 応答速度や動作 温度等についての様々な限界を打破できる新型平面表示 素子としてその実用化が期待されている1)。現在研究さ

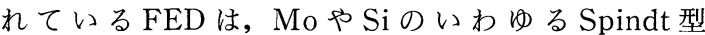
ティップ2)をマトリクス化した 2 次元アレイから電界放 射される電子を加速しスクリーン上の蛍光ピクセルに照 射することにより所望の色抢よび輝度を出す，約 $1 \mu \mathrm{m}$ スケールの集積回路システムである(図 1 上図) ${ }^{11}$ 。これ らの材料の仕事関数に対応した電位障壁を，表面に印加 した強電界下のトンネル効果によりそれらの固体から電 子を引き出す必要がある (図 2 左図) が，動作電圧を低下 させるためには, 局所電界 $E_{\mathrm{m}}$ がマクロ(平均)電界 $E$ に比べ大きく増大するように先鋭なティップ形状が使用 されている。図3に形状効果による局所電界が増大する 様子を含め(挿入図)，局所電界増大因子 $\beta\left(=E_{\mathrm{m}} / E\right)$ の

*大阪大学大学院工学研究科（干565-0871 大阪府吹田市山田 丘 2-1)

Graduate School of Eng, Osaka Univ (2-1, Yamadaoka, Suita-shi Osaka 565-0871)

* 高知工科大学 工学部（率782-8502 高知県香美郡土佐山田町 宮ノ口 185)

Kochi Unıv of Technology (185, Miyanokuchı, Tosayamada-cho, Kami-gun, Kochi 782-8502)
形状依存性の一例を示している ${ }^{3)}$ 。因に上述のティップ の曲率半径は, $20 \mathrm{~nm}$ 程度のものが用いられているが, 図 3 に示すごとく $\beta$ は局所構造に強く依存しているの で各ティップを精度良く作製する必要があり，FEDの 開発課題の一つとなっている。そこで，次世代の FED では，例えば図 1 下図に示すような，もっと簡素な構造 で, 安価なシステムが要求されている4)。このような状 況下で，ダイヤモンド，ダイヤモンドライクカーボン (diamond-like carbon, DLC)やカーボンナノチューブ などのような炭素系材料から比較的低いマクロ電界強度 に打いて電子放出が観測された4)。このため，これらの 材料は化学的にも物理的にも安定であることもあって, 現在盛んに研究が行われている。本稿ではダイヤモンド を中心として，その電子放出特性の概要を述べる。

\section{2. ダイヤモンドからの電界放射特性}

ダイヤモンド冷陰極の研究は，水素化ダイヤモンド表 面が負性電子親和力 (Negative Electron Affinity, NEA) $)^{5)}$ ，すなわちダイヤモンドの伝導帯最下端のエネ ルギー位置が真空の最低準位である真空準位より高い状 態を示す (図 2 右図)ことが見出されて以来盛んに行われ ている6)。この NEA 特性は, 広いエネルギーギャップ (ダイヤモンドでは $5.5 \mathrm{eV}$ )を有する軽元素材料でしば しば観測されているが，伝導帯の最下端近傍の電子状態 は反結合軌道で構成されているので, 材料の NEA と安 定性とは直接的には関係しない。なお，典型的な表示素 

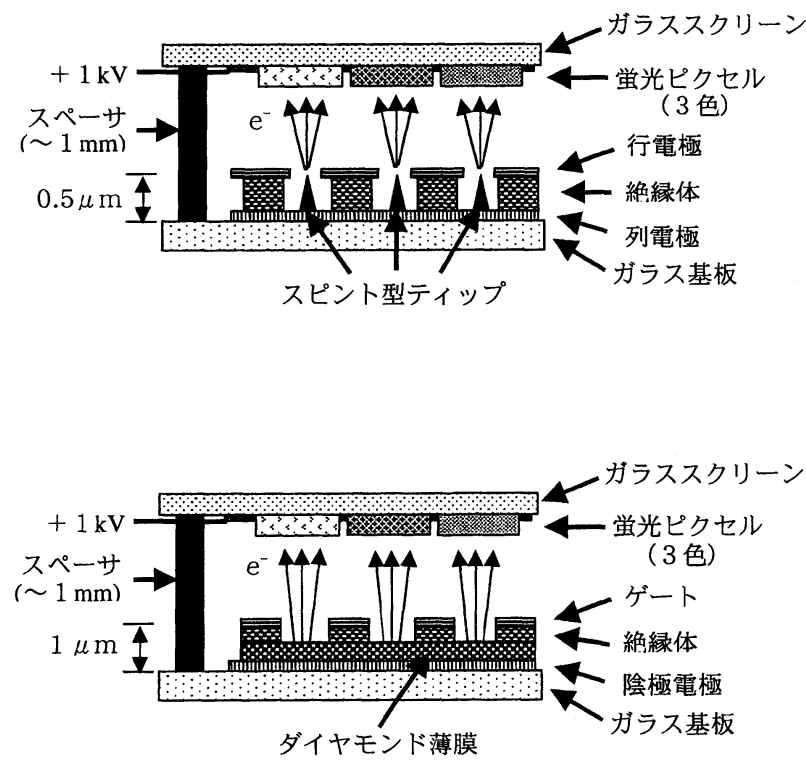

図 1 スピント型ティップ(上)およびダイヤモンド薄膜(下)を用いたフィールドエミッション ディスプレイ (FED)の概念図
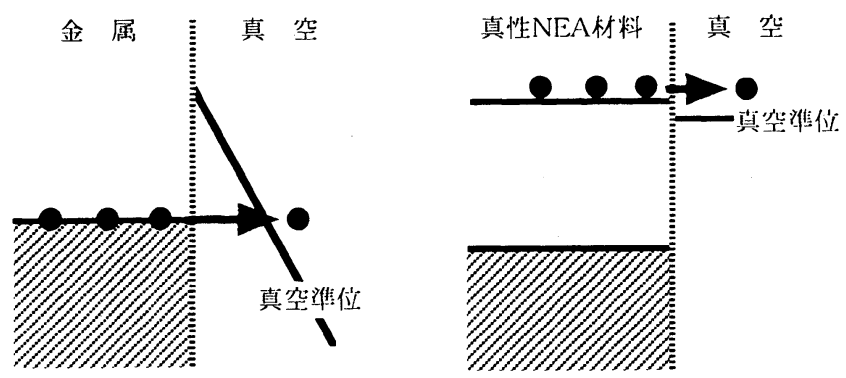

図 2 各種電子エミッターにおける電子エネルギー状態図：真空に強電界を印加する電界放射型(左), および NEA 特性を活用する内部励起型(右)

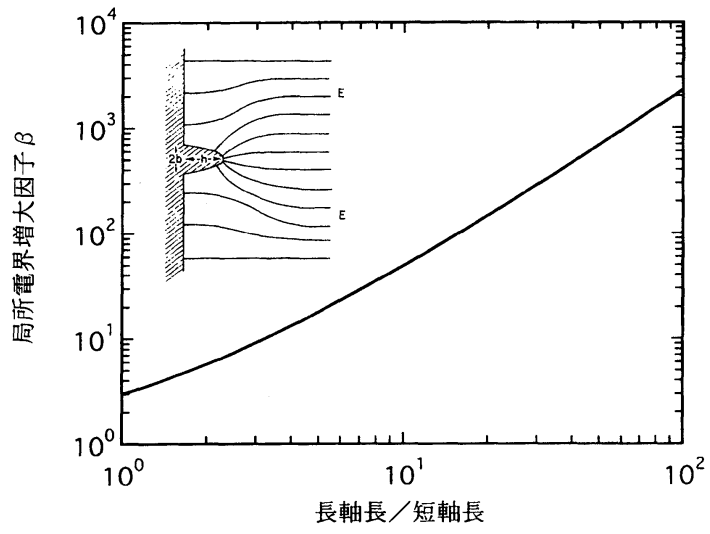

図 3 棈円微小突起による局所電界増大因子 $\beta\left(=E_{\mathrm{m}} / E\right)$ の形 状依存性

横軸は楕円体の長軸長 $(h) /$ 短軸長 $(b)$

挿入図はマクロ(平均) 電界 $E$ 微小突起先端で $E_{\mathrm{m}}$ に増 大される様子を示す模式図
子では, 例えば蛍光スクリーンへの加速電圧が $2 \mathrm{kV}$ と すると, $0.1 \mathrm{~mA} / \mathrm{cm}^{2}$ 程度のエミッション電流密度が必 要であるので1), この電流密度が表示素子用電子源とし ての実用的な判断基準の一つの目安であるが，これを上 回る炭素系電子放射データが得られ始めている7)。また, 封入した表示素子の 2 万時間程度の耐久試験も行われて いる8)

\section{1 多結晶ダイヤモンド薄膜}

図 4 に典型的な報告例として示しているように，多結 晶ダイヤモンドからの電子放出は, 粒塊のサイズに反比 例した放射電子電流が観測されたため, 粒界の伝導性に 強く依存すると考えられている4)。また，多結晶ダイヤ モンド薄膜から再現性良く，安定に，しかも低い電圧 (マクロ電界)で電子放出が生じるが，より高いメタン濃 度で作製した膜が，より低電界において電子放出が可能 であったため, ダイヤモンド膜中に含まれるグラファイ 


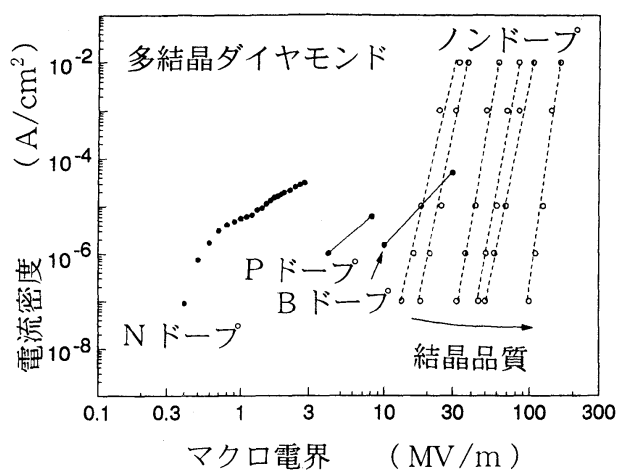

図 4 電界放射型ダイヤモンド薄膜電子エミッタにおける放射 電流密度のマクロ電界依存性の典型例4)

トが電子放出に関わっている可能性が高いことが報告さ れている9。最も低い閾值マクロ電界はナノメータサイ ズの微結晶ダイヤモンドにおいて観測されている。更に， ホウ素ドープしたダイヤモンドの閾值マクロ電界は高く, リンドープした試料では少し下がり, 窒素ドープした試 料の場合には $0.5 \mathrm{MV} / \mathrm{m}$ のマクロ電界で電子放射が開 始されるとの報告もある ${ }^{10)}$ 。

他方, 紫外光励起により放出された光電子電流の 2 次 元分布と電界放射電子電流の 2 次元分布が全く異なるこ とが指摘されている 薄膜材料の電界放射による電子放出は, 膜から均一に生 じるのではなく, ランダムに存在する局所的電子放出点 (エミッションサイト)から起きていることが明らかにさ れた。なお, 表示素子として利用可能な電子源となるに は, $10^{6} \mathrm{sites} / \mathrm{cm}^{2}$ 以上のエミッションサイト密度が必 要であると言われている4)。

これに対し，Xu等は, 誘電体であるダイヤモンド中 に形成された導電性チャネルを伝って基板から電子放出 面に電子が供給されるというモデルを提案し, この導電 性チャネルは，ダイヤモンド膜中に散在するグラファイ 卜領域が連結することにより形成されると推察してい る ${ }^{11)}$ 。また, Shovlin 等は, ダイヤモンド膜表面に薄く 金を蒸着した場合の電子放出特性が，金薄膜を蒸着しな い場合とほほ同一であるという実験事実から, 電子放出 が表面にはあまり強く依存しない絶縁破壊による導電性 チャネル形成モデルを提案している Huang 等は, バンドギャップ中の久陥準位からの電子 放出の可能性を示唆している ${ }^{13)}$ 。

\section{2 ダイヤモンドエミッタアレイ}

ダイヤモンドの形状加工は容易でないが, 浅野等はダ イヤモンド粒子を選択的に成長させた後, イオンミリン グによって先鋭なダイヤモンド錐のアレイを ${ }^{14)}$, 岡野等 はモールド法によりピラミッド型のダイヤモンドアレイ

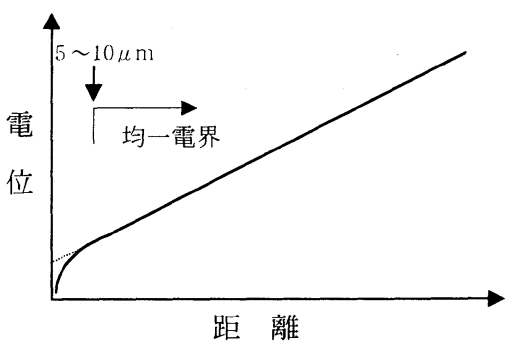

図 5 電界放射型電子エミッタにおけるダイヤモンド膜表面近 傍の電位の距離依存性(模式図)

エミッタ表面に近づくにつれ電位が急速に下がり, 電 界は増大する

を15)，それぞれ作製している。しかし，残念ながらアレ イ化の基本ティップ構造がダイヤモンド膜の微細構造よ りも桁違いに大きいこともあり，アレイ化のメリットは 必ずしも明瞭にはならなかった。また, シリコンやモリ ブデンのエミッタアレイに多結晶ダイヤモンドを被覆し たり ${ }^{16)}$, ティップの先端に単結晶ダイヤモンド粒子を成 長させたりする試みも行われて扔り ${ }^{17)}$, 動作電圧の低下 が報告されている16)。これらの試みは, いずれの場合も 作製プロセスが複雑であるので, 形状加工を必要としな い, より単純な電子放出素子の作製プロセスを目指す次 世代 FED (図 1 下図)の目標からは多少ずれている。

\section{3 電界放射のための予備処理}

ダイヤモンド薄膜や DLC 薄膜からの電界電子放射に おいて, 安定した電子放射が安定に生じるようにするた め,「活性化」(“activation”), あるいは「初期化」 (“initiation”)などと呼ばれる予備処理が重要であると しばしば言われている。このことは, エミッションサイ トが, 作製したままの薄膜中に始めから存在していると は限らず, 上記の予備処理過程で形成される可能性を示 している。例えば, 電界印加初期には, 短時間 $(200 \mathrm{~ns}$ 程度)の真空アーク放電が発生し, 微細なクレータや ティップ構造が形成されるとの報告もある ${ }^{18)} 。$

低マクロ電界での電子放出が膜中の導電性チャネルや 欠陥によるものであるとすると, 予備処理過程では表面 形状変化のみに限らず膜中の構造変化も誘起されている 可能性もある。 $\mathrm{sp}^{3}$ が支配的なアモルファスカーボン (ta-C) 膜は, 本来極めて高抵抗であるが低マク口電界で の電子放射が見出される場合には $\mathrm{sp}^{2}$ 結合を相当量含む 低抵抗膜となっている。

ダイヤモンドからの低マクロ電界での電子放出がダイ ヤモンド薄膜の微細構造等に起因する局所電界集中によ るものであるとすれば，電位の空間分布は模式的に図 5 に示すように, 表面近傍で急激に変化すると考えられる が，最近実測された電位分布によると，試料表面近傍に 
おける電界増大効果が実験的に確かめられている ${ }^{19)}$ 。

\section{4 単結晶ダイヤモンド}

水素終端ホウ素ドープ p 型単結晶(111) ダイヤモンド の場合には，Bandis 等が行った電界放出電子と光電子 のエネルギー分布の同時測定により，ダイヤモンドの価 電子帯の電子が強電界により直接真空へトンネル効果に より遷移することにより電子放出されるのであって，伝 導帯の電子は電子放出には関与していないことが明らか にされた ${ }^{20)}$ 。誘電体材料の電界放射の場合には，通常電 子放出面とは反対側の誘電体裏面に陰極電極が設けられ, 真空に置かれた陽極に対して電圧が印加されるので，誘 電体材料にもその誘電率に応じた電圧降下が生じる ${ }^{16)}$ 。 このため, 電子放出表面の電位が明瞭でなくなる問題が あるので, 放出電子のエネルギー分布を計測しても必ず しも機構解明には結びつかない。そこで, 電界放出電子 と光電子のエネルギー分布とを同時に測定すれば，後者 により電子放出表面の電位が決定されるので, この問題 が明瞭に解決できる。このように，Bandis 等の研究方 法は電子放出の機構解明に非常に有用である。

\section{5 電子放出機構}

電界放射に基づく電子放出の場合には，放射電子電流 密度 $J$ は次の Fowler-Nordheim 方程式により記述され $る^{21)}$ 。

$$
J=a E^{2} \exp \left(-b \phi^{3 / 2} / \beta E\right),
$$

ここで， $E$ は電界 $(\mathrm{V} / \mathrm{m}), \phi$ は電位障壁高さ $(\mathrm{eV})$ で, $a$ 拈よ゙ $b$ は定数である。この式から， $\phi$ やを見積 もると, $\beta=1$ とすれば, 通常 $\phi$ が $0.4 \mathrm{eV}$ 以下となり, $\phi$ を数 $\mathrm{eV}$ 程度とすると, 大きな $\beta$ が必要となってく ることが知られている。従って, 非常に小さな障壁高さ または極端な高電界が存在していることが示唆される。 障壁高さが非常に小さいことはエネルギー的観点から考 察すると現実的でないので，膜表面(近傍)には高電界領 域が局所的に存在している可能性が強く示唆される。

局所電界増大因子の観点からは，先鋭な形状を有する カーボンナノチューブは適切な電子放射材料と考えられ これまでに $0.8 \mathrm{MV} / \mathrm{m}$ の閾值マクロ電界が報告されて いる ${ }^{23)}$ 。しかし，一見平坦に思える単結晶ダイヤモンド の場合にも，マクロ電界 $50 \mathrm{MV} / \mathrm{m}$ に対し, $2 \mathrm{GV} / \mathrm{m}$ 程 度の局所電界の存在が示唆されているが，その原因は不 明である ${ }^{20)}$ 。他方, 多結晶ダイヤモンド膜に比べ, 遙か に平坦な表面形状を有する DLC 膜の場合でも同様な結 果が報告されている ${ }^{18)}$ 。 Robertson は，表面形状効果に 依らない局所的強電界形成機構として, 水素終端の局所 的不完全性により不均一電界が生じると言うモデルを提 唱している4)。

また，図５に示すような空間電位の距離依存性が観測 されているので, 表面近傍から少し離れた位置における 直線的変化を試料表面まで外挿することにより得られる
電位を試料表面電位(この電圧は電界放射印加電圧の一 部が絶縁性試料に分配されると考える)とし，この試料 へのバイアスにより電極から注入された電子がダイヤモ ンドの伝導帯や不純物帯へホットエレクトロンとして励 起され，表面まで効率良く輸送され表面から NEA 性や 低障壁のため効率良く電子放出されるとするモデルは問 題が多いことが分かる。

\section{3. ダイヤモンド内部の電子励起に基づく電子放 出}

NEA 表面を利用すれば，上述のような電界放射とは 異なった電子放出素子が実現できる可能性がある ${ }^{6)}$ 。 なわち，ダイヤモンドの伝導帯に励起された電子は表面 まで輸送され, ダイヤモンド膜が電荷を帯びない程度に 電荷供給が十分に行われれば，電子は自然にエネルギー の低い真空側へ放出されるので，表面近傍に強電界を印 加すること無しに電子が放出され，真空の質にあまり依 存しない電子放出素子が実現できると期待される。この ため，幾つかの試みが行われた。

\section{1 pn 接合構造}

Geis 等は, $\mathrm{n}$ 型ダイヤモンドから $\mathrm{p}$ 型ダイヤモンド へ電子注入し, $\mathrm{p}$ 型ダイヤモンドの NEA 表面から放出 させようとした ${ }^{23)}$ 。このため, 形成が容易な $\mathrm{p}$ 型ダイヤ モンド層に炭素のイオン注入を行うことにより，形成さ れた注入欠陥に基づく $\mathrm{n}$ 型伝導層を活用した pn 接合を 作製した。観測されたダイオード電流に対するエミッ ション電流の比(エミッション電流効率) は， $0.02 \%$ 以 下であったが，酸素リークの低真空下でも動作すること が示された。他方，注入欠陷による $\mathrm{n}$ 型層の形成でな く, $\mathrm{n}$ 型が期待されるリンドープのホモエピタキシャル ダイヤモンド層を用いて，pn接合を作製されたが，リ ンドープ層が高抵抗のため，観測された放出電子電流は fAオーダーであり，エミッション効率も桁違いに悪 かった ${ }^{24)}$ 。このため, ダイヤモンドの pn 接合構造を用 いた電子放出素子については，その後あまり研究が行わ れていないが, 現在 $\mathrm{n}$ 型ダイヤモンドの研究が進展し つつあるので, 高品質 $\mathrm{n}$ 型ダイヤモンドができれば新 たな展開が期待される。

\section{2 MIS 積層構造}

現状では保証できる $\mathrm{n}$ 型ダイヤモンド層の形成が容 易でないため，筆者等は，MIS（Metal-InsulatorSemiconductor) 型構造により，ダイヤモンドの伝導帯 へ電子注入できる電子放出素子の開発を行ってい る ${ }^{25) ~ 29) 。 こ こ て ゙, ~} \mathrm{M}$ は低抵抗電極層, I はアンドープ ダイヤモンド， $\mathrm{S}$ は水素化 $\mathrm{p}$ 型ダイヤモンドである。I 層に必要な高電界は，M 層と S 層との間に電圧を印加 することにより得ており，S 層はまた NEA 表面を有し ているため，電子放出面も兼ねている。まず最初に，こ 


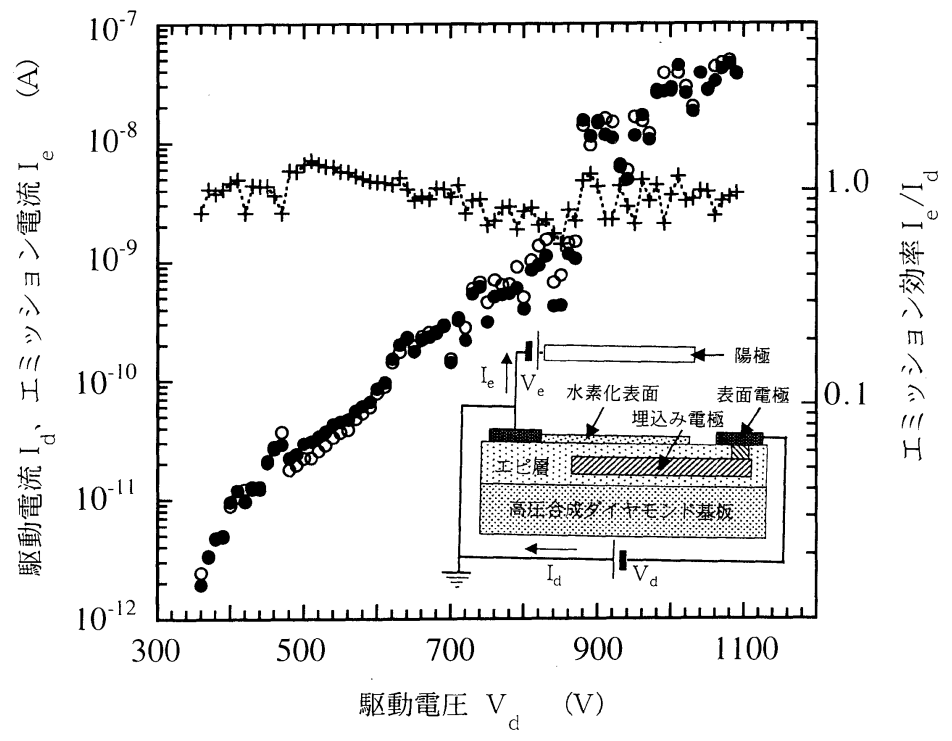

図 6 MIS ダイオード型単結晶ダイヤモンド電子エミッタの駆動電流 $I_{\mathrm{d}}(\bigcirc)$, エミッション電流 $I_{\mathrm{e}}(\mathbf{O})$, およびエミッション効率 $I_{\mathrm{e}} / I_{\mathrm{d}}(+)$ の駆動電圧 $V_{\mathrm{d}}$ 依存性

挿入図は素子の概念図

のような素子構造の作製が容易なシリコン基板上へ形成 した多結晶ダイヤモンド膜を用いて特性を調べた ${ }^{25)}$ 。そ の結果，エミッション効率は最大でも $2 \%$ 程度であり, 放出電流もnA オーダー程度であった。類似構造の素子 から,ダイヤモンドに特徵的な欠陥によるバンド A と 呼ばれる発光が電圧印加により観測されたため, 電子励 起は行われているが, 励起された電子が表面に到達する までに伝導帯より低エネルギーのギャップ中準位へ落下 していることが，低エミッション効率の原因と考えられ た ${ }^{26)}$ 。そこで, 結晶品質が現在最も良いと考えれている ホモエピタキシャル単結晶ダイヤモンドを用いて図 6 の 挿入図のような MIS 構造素子を作製した ${ }^{27)}$ 。こで， $\mathrm{M}$ 層はイオン注入と追成長技術を連結させて, 埋もれ た低抵抗層を形成した。得られたエミッション効率は, 最も良い場合には $100 \%$ に達するものが得られている (図 6$)^{28)}$ 。まだ, 放出電流は $0.2 \mu \mathrm{A}$, 電流密度は 20 $\mu \mathrm{A} / \mathrm{cm}^{2}$ 程度と少ないので, 今後更に安定性共々向上さ せる必要があるが, $10^{9} \mathrm{~V} / \mathrm{m}$ オーダーの強電界に耐え得 るダイヤモンドならではの電子放出ダイオード (Electron Emitting Diode, EED)への展開も期待できる ${ }^{29)}$ 。

\section{4.まとめ}

ダイヤモンド薄膜を中心とした炭素系材料からの電子 放出について現状を述べた。電界放射型の場合に観測さ れる低マクロ電界における電子放出の原因はあらゆる場 合について解明された訳ではないが，少なくとも局所的
に存在している強電界による電子放射が，その主たる原 因である可能性が高いことが示されている。固体表面か ら電子がトンネル効果により真空へ脱出する確率は, 試 料表面から真空側への $\mathrm{nm}$ スケールの電位分布に依存し ている。このため, 今後, 走査型プローブ顕微鏡などの 局所解析手法によりエミッション表面の nm スケールの 3 次元電位分布を明らかにするとともに, 放射電子の工 ネルギー分布の局所的解析が行なわれれば，これらの問 題は解決されるであろう。一方では, 実用レベルの放出 電子電流密度や耐久性を視野に入れた研究も行われるよ うになってきており7, ダイヤモンド薄膜を始めとする 炭素系材料からの電子放出に関する今後の研究展開が期 待される。さらに, ダイヤモンドを用いた真空の質に依 存しない電子放出素子の開発も興味ある課題であろう。

\section{謝辞}

本稿に記載されたデータの一部は, 日本学術振興会未 来開拓学術研究推進事業に基づく「ダイヤモンドによる 次世代電子エミッターの開発」プロジェクト(JSPS -RFTF 96 R 15401)により得られたものである。

(1999-5-17 受理)

\section{文献}

1) J. E. Jaskie ; MRS Bulletin, 21, (3), 59 (1996)

2 ) C. A. Spindt, I. Brodie, L. Humphrey and E. R. Westerberg ; J. Appl. Phys., 47, 5248 (1976) 
3 ) F. Rohrbach ; CERN Report, 71-5/TC-L, (1971) ; High Voltage Vacuum Insulation, ed. R. Latham (Academic Press, London, 1995)

4) J. Robertson ; Diamond Films and Technol., 8, 225 (1999)

5 ) F. J. Himpsel, J. A. Knapp, J. A. van Vechten and D. E. Eastman ; Phys. Rev., B 20, 624 (1979)

6 ）平木昭夫, 伊藤利道, 八田章光；応用物理, 66, 235 (1997)； 八田章光,伊藤利道, 平木昭夫；応用物理, 67, 1410 (1998)

7 ) 例えば Mater. Res. Soc. Symp. Proc. 558, to be published.

8 ) R. L. Fink, L. H. Thuesen, Z. L. Tolt and Z. Yaniv; Mater. Res. Soc. Symp. Proc. 558, to be published.

9 ) C. Wang, A. Garcia, D. C. Ingram, M. Lake and M. E. Kordesch ; Electron. Lett., 27, 1459 (1991)

10) K. Okano and K. K. Gleason ; Electron. Lett., 31, 74 (1995)

11) N. S. Xu, R. V. Latham and Y. Tzeng ; Electron. Lett., 29, 1596 (1993)

12) J. D. Shovlin and M. E. Kordesch ; Appl. Phys. Lett., 65, 863(1994)

13) Z. -H. Huang, P. H. Cutler, N. M. Miskovsky and T.E. Sullivan ; J. Vac. Sci. Technol. B, 13, 526 (1995)

14) T. Asano, Y. Oobuchi and S. Katsumata; J. Vac. Sci. Technol. B, 13, 431 (1995)

15) K. Okano, K. Hoshina, M. Iida, S. Koizumi and T. Inuzuka ; Appl. Phys. Lett., 64, 2742 (1994)

16) J. Liu, V. V.Zhirnov, G. J. Wojak, A. F. Myers, W. B. Choi, J. Hren, S. D. Wolter, M. T. McClure, B. R. Stoner and J. T. Glass ; Appl. Phys. Lett., 65, 2842 (1994)

17) E. I. Givargizov, V. V. Zhirnov, A. V. Kuznetsov and P. S.
Plekhanov ; J. Vac. Sci. Technol. B, 14, 2030 (1996)

18) O. Groning, O. Kuttel, P. Groning and L. Schlapbach ; Appl. Phys. Lett., 71, 2253 (1997)

19) 近藤利行, 長尾昌善, 後藤康仁, 辻 博司, 石川順三, 林和志, 小橋宏司; 第 46 回応用物理学関係連合講演会講演予行集, p. 797 (応用物理学会, 1999)

20) C. Bandis and B. B. Pate ; Appl. Phys. Lett., 69, 366 (1996) ; Phys. Rev. B, 52, 12056 (1995)

21) N.S. Xu ; High Voltage Vacuum Insulation, ed. R. Latham, p. 115 (Academic Press, London, 1995)

22) O. H. Wang, T. D. Corrigan, Y. J. Dai, R. P. H. Chang and A. R. Krauss ; Appl. Phys. Lett., 70, 3308(1997)

23) M. W. Geis, N. N. Efremov, J. D. Woodhouse, M. D. McAleese, M. Marywka, D. G. Socker and J. F. Hochedez; IEEE Trans. Electron Devices, 12, 456 (1991)

24) G. R. Brandes, C. P. Beetz, C. A. Feger and R. L. Write ; Diamond and Related Mater., 4, 586 (1995)

25) A. Hatta, K. Ogawa, N. Eimori, M. Deguchi, M. Kitabatake, T. Ito and A. Hiraki ; Appl. Surf. Sci., 117/118, 592 (1997)

26) T. Ito, K. Ogawa, N. Eimori, M. Deguchi, M. Kitabatake and A. Hatta ; Diamond and Related Mater., to be published.

27) M. Nishimura, A. Hatta and T. Ito ; Jpn. J. Appl. Phys., 37, L 1011 (1998)

28) T. Ito, M. Nishimura and A. Hatta ; Appl. Phys. Lett., 73, 3739 (1998)

29) T. Ito and M. Nishimura ; Mater. Res. Soc. Symp. Proc. 558, to be published. 